\title{
The Location of Lake Titicaca's Coastal Area During the Tiwanaku and Inca Periods: Methodology and Strategies of Underwater Archaeology
}

\author{
Christophe Delaere ${ }^{1}$
}

Published online: 22 November 2017

(C) Springer Science+Business Media, LLC, part of Springer Nature 2017

\begin{abstract}
For more than 30 years, numerous research projects have revealed the dense and complex human settlement of the lacustrine basin of Lake Titicaca in Bolivia and Peru. Physical evidence of such establishments has been discovered in plains, valleys, and highlands connected to the lake. These remains confirm human occupation and development in this environment, particularly during the Tiwanaku (AD 500-1150) and Inca (AD 1400-1532) Periods. The research project discussed in this paper includes consideration of submerged areas through underwater archaeology. This investigation involves analysis of two areas that have evidence of ancient human occupation but are poorly documented: the coastal and lacustrine regions. Due to its dominance in the landscape, Lake Titicaca has always been a major feature in the life and identity of populations of this vicinity. These inhabitants have developed socio-economic and ritual behaviours directly associated with the lake that have left cultural and material prints that are the foci of the present study.
\end{abstract}

Resumen Durante más de treinta años, numerosos proyectos de investigación han hecho evidente el denso y complejo asentamiento humano en la cuenca lacustre del Lago Titicaca (Bolivia, Perú). La evidencia física de este establecimiento había sido descubierta en llanuras, valles y elevaciones naturales conectadas con el lago. Estos restos confirman la ocupación humana y el desarrollo en este ambiente, particularmente durante los periodos de Tiwanaku (500-1150 d.C.) e Inca (1400-1532 d.C.). El proyecto de investigación discutido incluye la consideración de áreas sumergidas a través de la arqueología subacuática. Esta investigación implica el análisis de dos áreas que han sido parte de la ocupación humana antigua, pero están mal documentadas: las regiones costeras y lacustres.. Por su predominio en el paisaje, el Lago Titicaca siempre ha sido una característica importante en la vida e identidad de las poblaciones de esta vecindad. Estos habitantes han desarrollado conductas socioeconómicas y rituales directamente asociadas con el lago que han dejado una huella cultural y material que es el foco del presente estudio.

Christophe Delaere

cdelaere@ulb.ac.be

1 Université libre de Bruxelles (ULB), Brussels, Belgium 
Keywords Bolivia · Lake Titicaca · Tiwanaku and Inca cultures · Coastal area $\cdot$ Paleo-environment

\section{Settlement Patterns of the Lacustrine Basin}

Located at the Bolivian and Peruvian border, Lake Titicaca's lacustrine basin is one of the most important cultural epicentres of South America. Indeed, at the crossroads of many important travel and trading routes, this territory has contributed to the emergence of one of the most astonishing civilisations of the American continent between the sixth and the eleventh centuries AD: the Tiwanaku civilisation. This indigenous cultural formation, characterised by a homogenous material production, is responsible for the first organisation and occupation of the lacustrine basin territory. Study of Lake Titicaca cannot be dissociated from the analysis of this civilisation because this stretch of water represents the focal point of a cultural and territorial expansion in the Central Andes prior to the twelfth century. J. Janusek has perfected a chronology of this society evolution and marks its " $[\ldots]$ rise to power in $\mathrm{AD} 500-600$, its transformation at around $\mathrm{AD}$ 800-900, and its disintegration after AD 1000-1100 [...]" (Janusek 2013:198).

After the disappearance of the leading elite and the influence of Tiwanaku from the eleventh century, a new colonisation of Lake Titicaca and its islands has been documented in the first half of the fifteenth century. A conquering empire, the Incas, declared this territory the mythological birthplace of their dominant ethnic society. The attractiveness and importance of Lake Titicaca and its surroundings were related to its natural resources and strategic position, but its recognition as one of the most important cosmogonic centres of the Andean beliefs was also a matter of great significance. In a way of legitimisation of the new dominating group in power, the Incas symbolically and physically reclaimed these sacred spaces. According to Bauer and Stanish ${ }^{1}$ (2001: 53), the Incas conducted two incursions in this region. The first, a military campaign lead by Viracocha Inca, is characterised by a permanent occupation of the territory [ \pm AD 1400-1440]. The second is put in place by his son, Pachacuti, and marked by an authoritarian reinforcement of the society in power, which primarily includes an appropriation of the Island of the Sun through the building of new sanctuaries and temples [ \pm AD 1440-1532]. During the Spanish colonisation in 1532, Lake Titicaca was said to be one of the wealthiest and most densely populated areas of Peru (Stanish 2011: 26).

The lacustrine basin spreads over a high altitude plateau at $3809 \mathrm{~m}$ above sea level and is bordered by mountains with summits above $6000 \mathrm{~m}$. This "inland sea", which has an $8560 \mathrm{~km}^{2}$ surface area, has allowed for the development of a dozen of different civilisations (Stanish 2011: 10). This vast stretch of water was not an impediment but, on the contrary, has favoured human settlement on its shores and islands by creating a unique ecosystem in the middle of a semi-arid territory. It has offered many "material opportunities" that have facilitated human integration (Binford and Kolata 1996: 23) (Fig. 1).

\footnotetext{
1 They base their reasoning upon the chronicle written by Cieza de León who visited this region in 1548.
} 


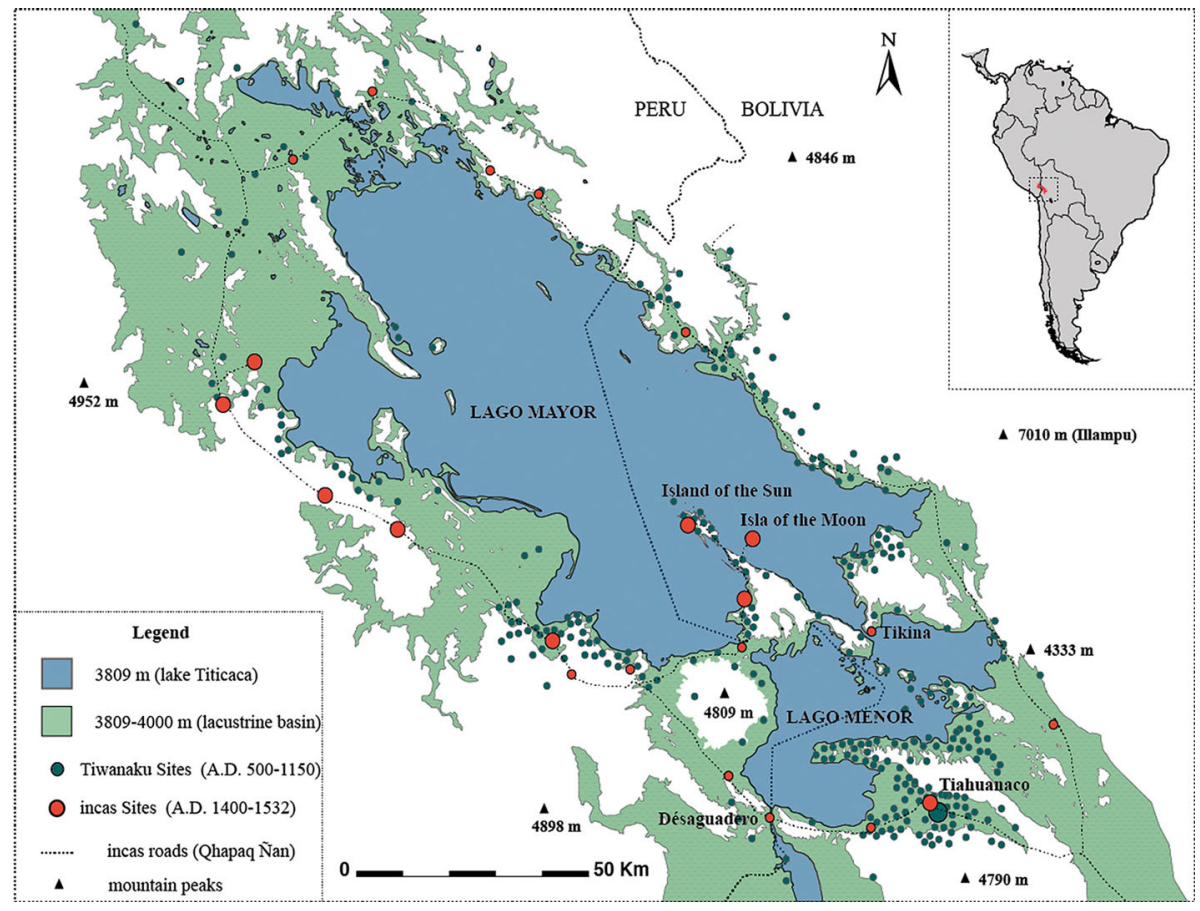

Fig. 1 Settlement patterns of the lacustrine basin (Peru/Bolivia) (Delaere 2016)

\section{Lacustrine Landscape Alteration}

The ecosystem associated with Lake Titicaca is delimited by the drainage basin that includes territories, valleys, plains, and mountains whose waters converge towards the lake. Depending on the altitude and the zones irrigated by rivers, the environment presents a large ecological diversity inside a limited territory. The drainage basin covers a $57,340 \mathrm{~km}^{2}$ surface area and is located between the modern countries of Peru $(60 \%)$ and Bolivia (40\%) (Binford and Kolata 1996: 24). The general geomorphology is divided into three areas: the lake (15\%), the lacustrine basin (27\%), and the mountainsides $(58 \%)$ (Boulangé and Jaen 1981: 272, tableau 1). The natural and cultural landscape of modern populations (of the entire territory) is shaped by the drainage basin. These inhabitants live mainly at the edge of the lake, throughout an average surface area of $15,480 \mathrm{~km}^{2}$, and the lacustrine basin, between 3809 (the lake) and $4000 \mathrm{~m}$ in elevation. The majority of archaeological sites from the Tiwanaku and Inca Periods are also positioned in this exact region, which allowed intensive agricultural exploitation and animal breeding (Stanish 2001: 196) (see Fig. 1).

With a $200 \mathrm{~km}$ maximum length and a $70 \mathrm{~km}$ width, Lake Titicaca is one of the largest lakes of the continent. Like a small South American Mare Nostrum, Lake Titicaca with its size and its surface area has more in common with an inland sea where tides, important lacustrine currents and storms dangerous for navigation occur. It is the highest navigable lake in the world, and it is divided by the Strait of Tiquina into two basins: Lake Chucuito (or Lago Mayor) in the northern part, and Lake Huiñaimarca (or Lago Menor) in the southern part (see Fig. 1). 
If the drainage basin of Lake Titicaca consists of three main spaces, one of these elements in particular is poorly studied because of its inaccessibility: the lake itself. To discern the significance of the lake for the ancient populations requires an assessment of the present-day submerged sites and an analysis of in situ material remains of human exploitation of the lake. Establishing a research project using diving operations is thus essential, allowing a more direct approach.

Between 2012 and 2014, around 20 underwater stratigraphic test-trench excavations of $4 \mathrm{~m}^{2}$ have been carried out in ten different locations into the lake. The result has uncovered a dense and complex archaeological heritage from the last two millennia. All the artefacts are from submerged find contexts situated in the coastal region at depths varying from 2 to $12 \mathrm{~m}$. In 2013 and 2014, the water level of Lake Titicaca was at $3809.7 \mathrm{~m}$ elevation. The low water level of the lake is quite variable. From a seasonal point a view, the dry season has a statistical average level of $3809.4 \mathrm{~m}$. But from a historical point of view, an absolute water level of $3806.7 \mathrm{~m}$ was recorded in 1944 (Ronchail et al. 2014: 6). As a result, some of the contexts discovered in 2013 and 2014 have been documented as submerged at the time but in a coastal sector that is not permanently under water (Delaere 2016: 15-19).

Understanding the historical fluctuations of Titicaca is primarily relevant for understanding human activity associated with the lake. Paleo-environmental reconstructions of the lacustrine basin during the Tiwanaku and Inca Periods are essential in order to approach territorial settlement geo-strategies that include landscape alterations. Lake Titicaca is part of the high-altitude lakes category; the water level is mainly determined by the ratio between hydrologic influxes caused by rainfalls and the melting of glaciers, and water evaporation of the lake during sunny periods (Ronchail et al. 2014: 6). As soon as an imbalance appears between these two phenomena, an increase or decrease of water volume can be observed through changes in lake level elevation. In Lake Titicaca, these fluctuations are noticeable annually, between dry seasons and wet seasons. This imbalance can also be noted on a historical perspective. Actually, paleo-limnologic data shows that the water level of Lake Titicaca was far from constant in the course of the last three millennia. Binford et al. (1997: 246; Fig. 7) suggest that between AD 500 and AD 1150 the lake water level was between 3805 and $3810 \mathrm{~m}$ in elevation. The coastline during the Tiwanaku Period was between the modern level and $5 \mathrm{~m}$ depth. Mourguiart et al. (1992: 879) state that at the beginning of the Tiwanaku Period (AD 500), the water level was not only between 5 and $6 \mathrm{~m}$ lower than the present level, but the lacustrine landscape was different and the whole coastal area of this period is presently submerged.

The impact of climate variations on the lake's water volume is difficult to quantify. In some parts of the lacustrine basin, if the water level increases or decreases only $1 \mathrm{~m}$, the coastal limits can shift to several kilometres (Binford and Kolata 1996: 38). These fluctuations affected settlement patterns and activities around the lake.

In addition to geo-morphologic criteria, the area also must be considered using anthropogenic criteria: (1) the lacustrine area, (2) the coastal area (geo-strategic transition zone), and (3) the island or continental area (permanent settlement zone). Following an estimate made by Ponce Sanguinés (1992: 33), every $1 \mathrm{~m}$ variation of water level effects on average $290 \mathrm{~km}^{2}$ of territory surface area, whether it is to the benefit or detriment of occupied space. Nowadays, Lake Titicaca (3809 $\mathrm{m}$ elevation) has a surface area of $8560 \mathrm{~km}^{2}(\alpha)$ whereas exposed land under $4000 \mathrm{~m}$ elevation (principal population zone) has a surface area of $15,480 \mathrm{~km}^{2}(\beta)$; thus the total equals $24,040 \mathrm{~km}^{2}\left(\sum\right)$. This corresponds to $\left(\left[\sum\right]-[\beta]\right)=(\alpha)$ or $\left(\left[\sum\right]-[\alpha]\right)=(\beta)$. Therefore the coastal area $(\chi)$ is variable; this region is situated at the junction between the submerged area $(\alpha)$ and the exposed area ( $\beta$ ) (Fig. 2) (Delaere 2016: 18). 
The concept of 'Maritime Cultural Landscape' (Westerdahl 1992: 6-14) can be applied to the lacustrine area as "Lacustrine Cultural Landscape". This concept not only includes the material culture usually studied but also "[...] the whole network of sailing routes, old as well as new, with ports and harbours along the coast, and its related constructions and remains of human activity, underwater as well as terrestrial" (Westerdahl 1992: 6). This interpretative tool is perfectly adapted to the analysis of Lake Titicaca because it enables to study past navigation extensively by incorporating all parameters and areas, submerged or not, within a region of study culturally homogenous and indivisible. Therefore, the location of (paleo) shores that belong to ancient periods, inevitable "transit points" (Westerdahl 1992: 6), is essential in order to reconstruct the lacustrine cultural landscape of each period.

\section{Location of the Coastal Area: Methodology}

Since 2014, the interventions in Lake Titicaca have systematically followed three important steps in order to locate and select possible archaeological sites: (1) define an area of study based on predictive preliminary models, (2) perform underwater exploration with the aim of defining, through different in situ observations, where to test, and (3) excavate several test areas in order to analyse the potential site in connection with sedimentary accumulation and the percentage of associated artefacts.

One of the main difficulties of this research project is linked to the present surface area of Lake Titicaca: $8560 \mathrm{~km}^{2}$. Underwater archaeological work is slow, and the excavation rate does not exceed $75 \mathrm{~m}^{2}$ per year of intervention. Statistically, it is necessary to reduce, first, the number of potential intervention areas because "[...] we must be able to predict the approximate location of sites so as to minimize the search area [...] (Flemming 1983: 138, quoted by Evans and Keith 2011: 168). The predictive model created for Lake Titicaca takes into account: (1) anthropogenic criteria specific to settlement dynamics, (2) geo-morphologic criteria that include topography and bathymetry, and (3) paleo-environmental criteria that reference natural landscape alterations over time. In this respect, it is worth noting that the predictive model of the Tiwanaku Period (AD 500-1150) does not apply to the one of the Inca Period (AD 1400-1532): the lacustrine area managed, the territorial occupation strategies, and the natural landscape are completely distinct.

When the survey area is determined by a predictive model, each relating to its period, the second step involves in situ observations within the scope of diving surveys around a potential archaeological zone. In general, survey results are negative because one of the

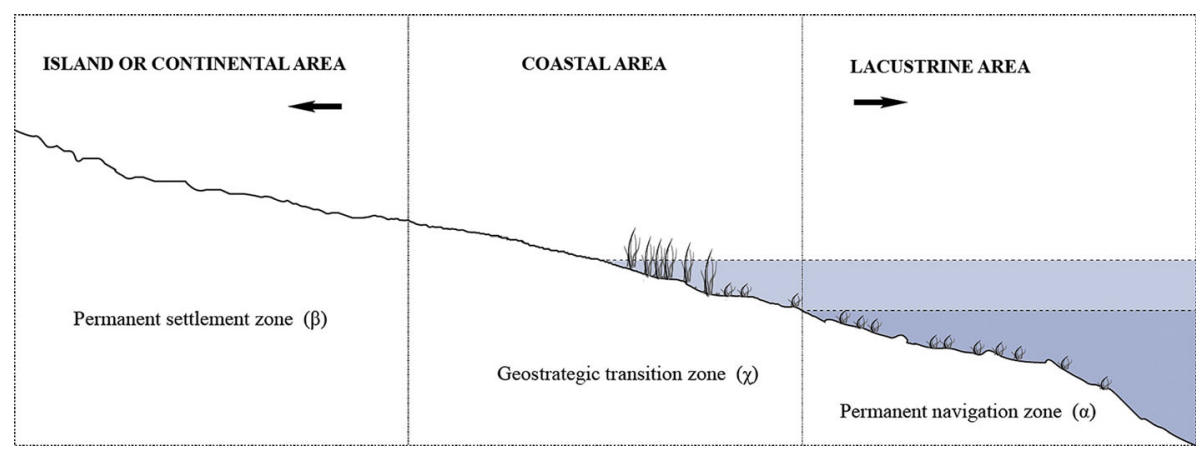

Fig. 2 Geo-morphology of the lacustrine basin following anthropogenic criteria (Delaere 2016: 18) 
main characteristics of high altitude lakes is the thickness of sedimentation. Artefacts are rarely visible on the lake bed and geophysical exploration data are not conclusive. So, dynamic surveys are also carried out. The latter are of a "negative-positive" type that consists of setting up of $0.25 \mathrm{~m}^{2}$ test pits at evenly-spaced intervals, $4 \mathrm{~m}$ apart, along a graduated axis that respects the principal inclination of the lake bed.

S. de Borhegyi notes that excavation issues and techniques related to submerged survey contexts could or "would need to be regarded as an extension of the ones already encountered and solved by dry land archaeology" (de Borhegyi, cit. in Bass 1970: 17). When dynamic exploration results are positive, i.e., when artefacts are present, a third step takes place that consists of setting up, on the lake bed, a $4 \mathrm{~m}^{2}$ test trench. This is done not only where the number of artefacts are important, but also as a way to maximise the site representativeness in terms of surface area and strategy. Today's maritime (or lacustrine) archaeology, as stated by J. Flatman, is "[...] increasingly simply just archaeology" (2011: 311). Diving is not the objective but the required medium through which the specific area can be reached.

During each excavation campaign a particular site is selected, every time in the same sector of the lake, where extended excavations are performed. This sector is the Island of the Sun and is of great interest because of different methodological reasons. First, this island is, by definition, a homogenous island territory surrounded by water. It has its own micro ecosystem and its dimensions $\left(14.3 \mathrm{~km}^{2}\right)$ are appropriate for underwater interventions. Second, this territory is characterised by a dense, complex, and uninterrupted settlement, which is well documented through archaeology (Bauer and Stanish 2001; Stanish and Bauer 2004; Seddon 1998). The Island of the Sun, inhabited during the Tiwanaku Period, was the focus of ideological re-appropriation by the Incas. Therefore, the diachronic evolution of the cultural landscape is easily observable through the analysis of the variability of the material culture and settlement strategies. Third, this island is an ideal area of study because it requires navigation, a cultural practice poorly documented during the prehispanic period. Navigation is a fundamental way of movement in order to link this island region to the continent. Theoretically, the circulation of goods and persons must have left a material imprint on the coastline. The goal was to identify access zones to the Island of the Sun in a diachronic perspective.

\section{Description of the Island Coastal Area: Excavation Strategies}

At the Island of the Sun, Stanish and Bauer identified, thanks to the distribution analyse of ceramic fragments on the island territory, at least 28 settlement sites from the Tiwanaku Period (AD 500-1150) and 86 potential or confirmed archaeological sites from the Inca Period (AD 1430-1530) (Stanish and Bauer 2004: 31-35, Table 2.1) (Fig. 3). The settlement site close to the southern extremity of the island, and thus the nearest to the continent, belongs to the Inca Period: Puncu (site no 163, Stanish and Bauer 2004: 208). Starting from this period, the access zone to the Island of the Sun from the peninsula of Copacabana might have possibly been in the vicinity of this terrestrial site. According to the same authors, Puncu is a 0.28 ha site with a hypothetical function of "habitation, possible quay" (2004: 208) (see Fig. 3).

The geo-morphology of the Island of the Sun's southern extremity corresponds to an uneven coastline of $700 \mathrm{~m}$ width and a west-east orientation. The western portion is constituted by cliffs that continue into the lacustrine waters, whereas the eastern portion, 


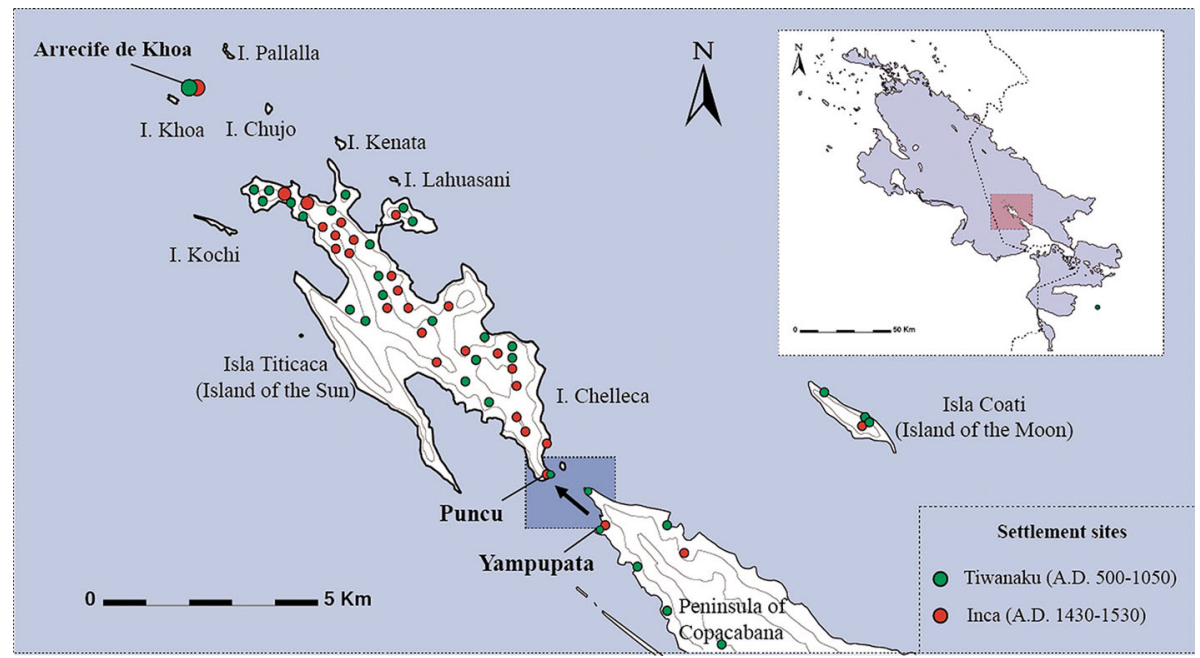

Fig. 3 Strait of Yampupata between the Island of the Sun and the peninsula: Puncu and Yampupata (Delaere 2016: 91)

with a quasi-identical morphology except for stronger erosion and weaker inclination, forms a massive headland constituted of monumental stones overhanging several metres above the lake surface. The Islet of Chelleca is located $260 \mathrm{~m}$ east of the latter and is divided by a channel (see Fig. 3). Theoretically, the coastal area utilised during ancient periods must be situated on a $\pm 20 \mathrm{~m}$ width band along the $700 \mathrm{~m}$ cliffs, representing a potential surface area of investigation of $14,000 \mathrm{~m}^{2}$.

Information has contributed to focusing the search zone "at the southern extremity of the island [of the Sun], and in front of Yampupata, [where] there is a small harbour, or landing stage, which is part of a very ancient road [...]" (Posnansky 1912: 14). In this example, the author specifically mentions the presence of a mid-twentieth century structure. By exploring the coastline, this small harbour which had sheltered steamboats as early as the end of the nineteenth century has been identified, and its L-shaped superior part is currently under 50 to $120 \mathrm{~cm}$ of water. This example demonstrates the importance of understanding the lake's fluctuation patterns in the study of underwater heritage.

Twelve test trenches of $4 \mathrm{~m}^{2}$ have given a total surface area of $48 \mathrm{~m}^{2}$ of excavations and $3600 \mathrm{~m}^{2}$ of survey. The focus of these investigations has been centred on two distinct sectors identified during survey (Fig. 4):

- The Puncu 1 sector is located at the southern portion of the headland that forms the south-east extremity of the Island of the Sun. Seven test trenches have extended from underneath the submerged L-structure and have followed three separate axes. The sector inclination is steep with a $20 \mathrm{~m}$ difference of elevation over $40 \mathrm{~m}$ (26.5 degrees inclination) from the shore to the open water.

- The Puncu 2 sector is located at the eastern portion of the headland. Five test trenches have extended from the area of an underwater landscape irregularity characterised by a concentration of $2 \mathrm{~m}$ wide stones at $4 \mathrm{~m}$ depth. This specific anomaly can theoretically be attributed to a paleo-shore imprint so four successive test trenches were opened there in order to create an archaeological trench. In this sector, the inclination is less, a $9 \mathrm{~m}$ 


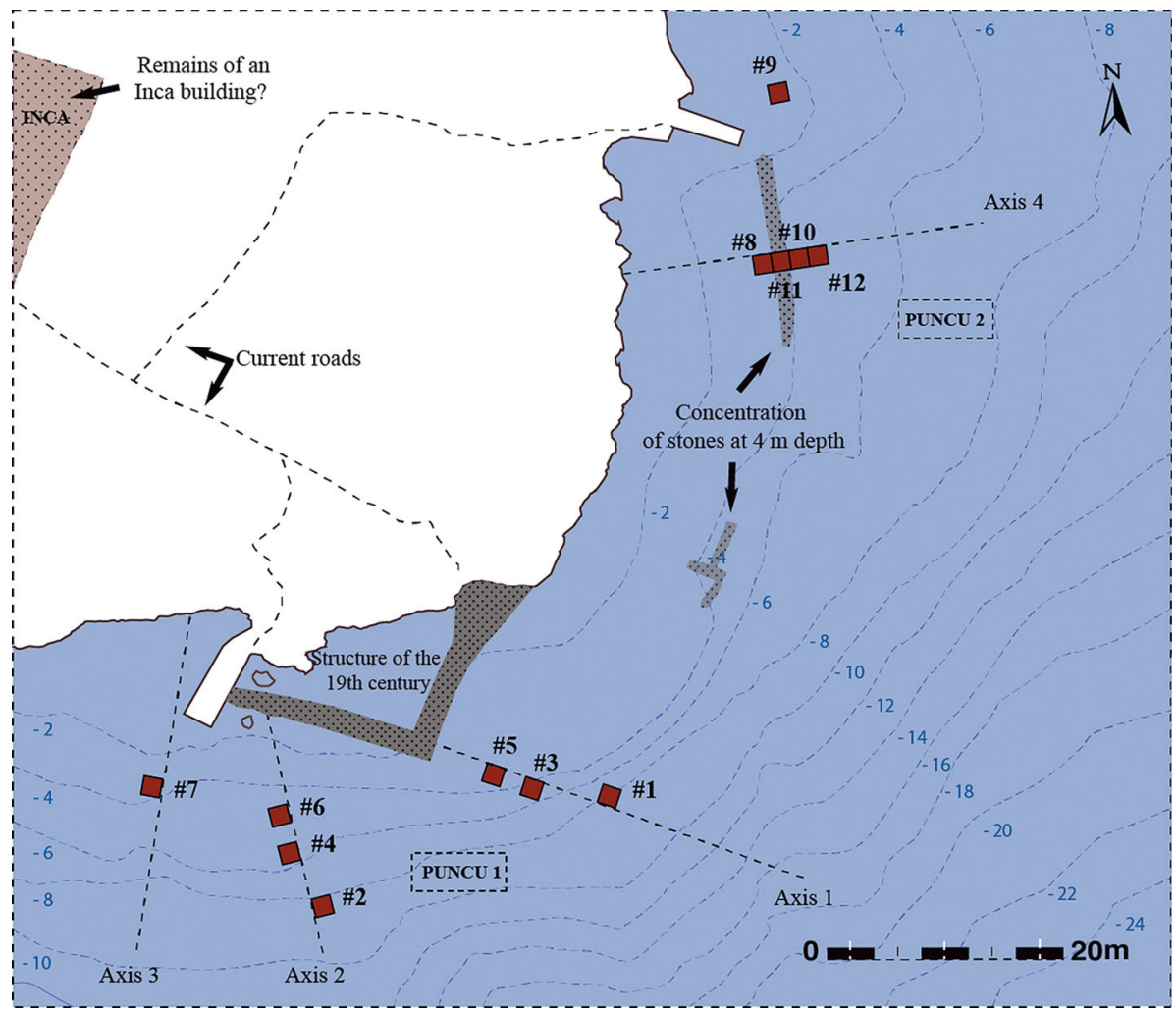

Fig. 4 Location of the 2014 excavations sondages test trench excavations-Puncu 1 and 2 (Municipio de Copacabana) (Delaere 2016: 103)

difference of elevation over $40 \mathrm{~m}$ (12.7 degrees inclination) from the shore to the open water.

This archaeological intervention orientation is not determined by the four cardinal points, instead, the dominant orientation of the lake bed was followed with, on one side, the uphill part (towards the bank) and on the other side, the downhill part (towards the lake). The test trench numbering corresponds to the establishment chronology of each of them across the excavation sectors. In order to identify and date the different paleo-shores of Lake Titicaca, several test trenches were established at various depths that follow the same axis in order not only to obtain a better site representativeness in terms of elevation but also in terms of surface area. Afterwards, a ceramic artefact contextualisation was implemented both in the cross-section (vertical contextualisation, artefacts temporal distribution) and in the plan perspective (horizontal contextualisation, artefacts spatial distribution). These two analysis strategies allowed for the establishment of a "scatter plot" of all the discovered artefacts in 3D. 


\section{Artefacts Vertical Contextualisation: Results and Discussion}

In the Puncu 2 sector, the excavation trench consisting of test trenches \#8, \#11, \#10 and \#12 (from uphill to downhill) was located $15 \mathrm{~m}$ from the present shoreline (see Fig. 4). The archaeological investigations not only have made it possible to identify remains of past occupation and activities, but also the marks of changes in the lake landscape over time.

First, sediment accumulation is characterized by an alternation of darker vegetation layers (slow and constant sedimentation interface of a lacustrine type) and light colored mineral layers composed of waste residues (coastal type interface composed of amalgamation and backwash). This contrast not only has facilitated the recording of the excavation but also one of the associated artefacts. Archaeological levels are only conserved in mineral layers (US2-US4-US6-US8-US10) and non-anthropogenic levels in organic layers (US1-US3-US7-US9) (Fig. 5). Then, some archeological layers are richer uphill, especially in test trench \#8, and gradually decrease in thickness downhill. This morphology is typical of the swash phenomenon present in the coastal areas: they are paleo-shores. The presence of numerous plant fragments (barks, branches, etc.) in the deepest layers (US 9-10) also corroborates the presence of non-submerged soil levels. In the latter example, this is an old vegetation cover partially preserved by anaerobic conditions following a rapid rise of the level of the lake. Finally, the excavation also revealed that the concentration of stones in test trench \#11 corresponds to an earlier development of the coastline not only to reinforce it, but also to delineate a relatively flat intermediate area (Fig. 5).

The stratigraphy of cross-section \#8-\#12 therefore documents partially the history of lake fluctuations, which are possible to quantify and date due to the presence of anthropogenic elements. The mineral layers retain archaeological material deposited in a secondary context during various erosion events of the sector (low lake level), and the organic layers document natural lacustrine sedimentation (high lake level) (Delaere 2016: 106-126).

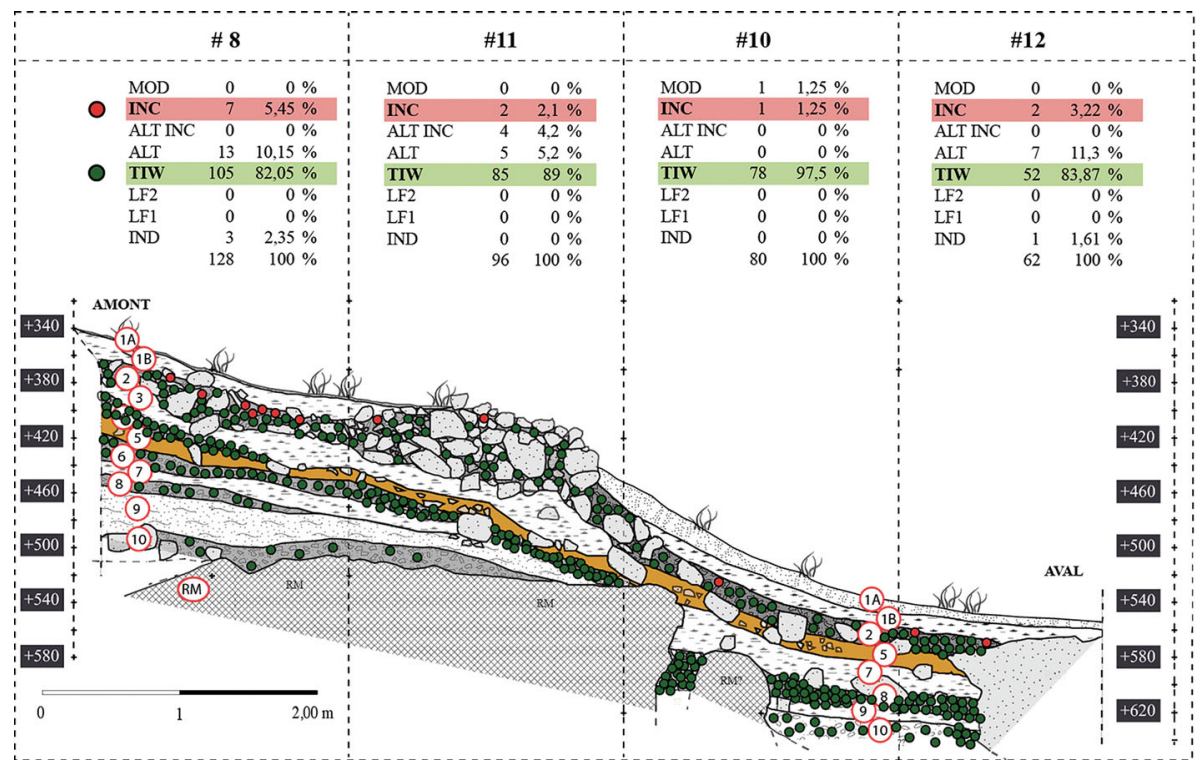

Fig. 5 Vertical contextualization of ceramic artefacts test trenches \#8-\#12 (Puncu 2) (Delaere 2016: 115) 
A total of 504 artefacts and ecofacts have been found in the trench: 370 ceramic fragments (73.4\%), 119 fragments of animal and human bones (23.6\%), three metal objects including one gold leaf $(0.6 \%)$, four manufactured stone elements $(0.8 \%)$, one fragment from an ceramic spindle whorl $(0.2 \%)$ and seven organic elements or samples $(1.4 \%)$. Among the ceramic artifacts, are 320 Tiwanaku fragments (AD 500-1150), 29 unidentified Altiplano fragments (AD 1150-1600), four Altiplano Inca fragments (AD 1400-1532), 12 Inca fragments (AD 1440-1532), one modern fragment ( $\geq A D$ 1825) and four indeterminate fragments $(1.1 \%)$. The distribution of the ceramic fragments within each stratigraphic unit (see Fig. 5), perceptible by the contextualization of the artefacts in the crosssection, dates the occupation or use of this area in relation to the lake fluctuation events. For example, at least two distinct water levels between AD 500 and AD 1150 can be identified (Fig. 6).

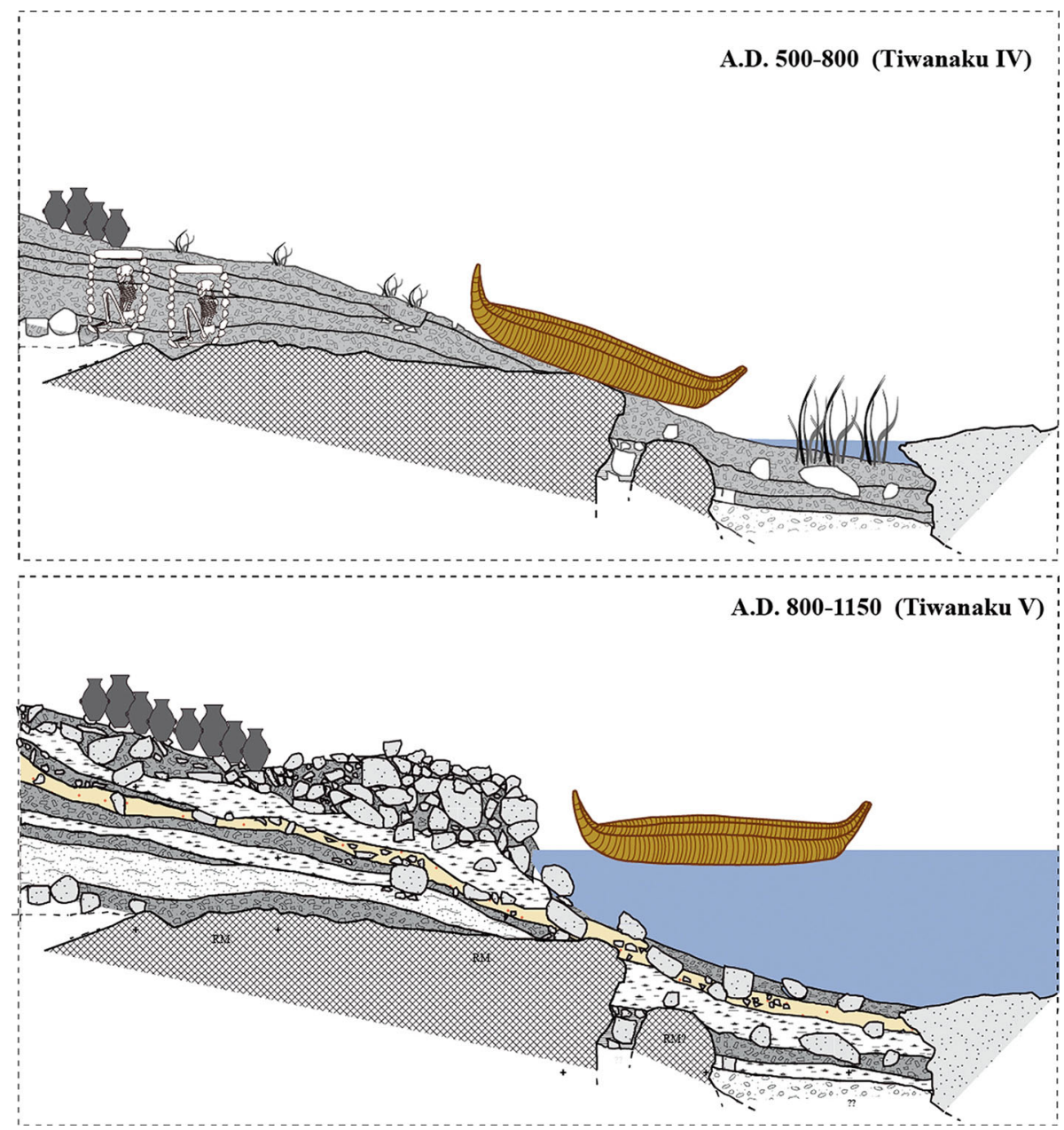

Fig. 6 Reconstruction cross-sections of the Tiwanaku coastal area (AD 500-1150) (Puncu 2) (Delaere 2016: 165) 
The majority of the materials date from the Tiwanaku Period $(86.5 \%$ of the ceramic fragments). There are no constructions; a single reinforcement of the bank has been erected during the last phase of the period (AD 800-1150) (see Fig. 6). In addition, the analysis of the artefacts makes it possible to identify the nature of the occupation; this sector corresponds not only to a harbour-like transitional area, but also to a coastal area of occupation and activities, now submerged.

The presence of ceramics of olla type (cooking, storage and transport of food) and tinaja (fermentation, storage and transport of beverages) documents the circulation of edible goods, whether it is for social, economic or ceremonial purposes. The presence of keros (individual drinking cup) can reflect the circulation of people, while that of incensarios or sahumadores (ritual ceramics) the circulation of prestige objects. Vasijas, keros and cuencos ceramics, as well as bronze tupus (clothe spindles), are associated as funerary furniture with the human bones of the lower levels. The presence of these graves (discovered in a secondary context), but also the presence of hearth remains, of instruments related to the wool spinning, and of stone weights for fishing nets, shows not only that this sector was not systematically submerged but that it was also used for specialized activities indivisible from a space located on the water's edge.

The majority of post-Tiwanaku ceramic fragments ( $\geq$ AD 1150), particularly those of the Inca Period (AD 1400-1532), were found in the Puncu 1 sector (see Fig. 4). There are many differences observable between these two sectors. First, the amount of post-Tiwanaku ceramic fragments is more abundant near the current coastline, while those of the Tiwanaku Period have been discovered in deeper waters (paleo-shore) and also in deeper stratigraphic units. Second, from a taphonomic point of view, ceramic fragments of this period are much less eroded; the finish and the iconography are regularly preserved. Actually, post-Tiwanaku fragments have been regularly found in layers of slow and constant sedimentation near the present coastline, indicating that the zone between 1 and $2 \mathrm{~m}$ of depth was already submerged during the Inca Period. Third, the discovery of a carved block of Andesite of Inca workmanship at $2 \mathrm{~m}$ depth (\#7) indicates, on the one hand, that this block of non-native geology of the island has been transported by boat and confirms that this shallow area was immersed during the Inca Period. The block actually results from an accident during the offloading; this stone, under water, could not have been recovered when it was still a valuable object. Finally, we note that the forms of the postTiwanaku ceramics are distinct from those of earlier periods. The cuencos, in particular, represent the majority form of the post-Tiwanaku dump. These are local workmanship, but of Inca style, and seem to have been produced by the local people for foreign pilgrims. Indeed, it is a small bowl that had to be an individual object, whether it is for a ritual function (libation) or simply to consume food (bowl of a pilgrim). Almost no post-Tiwanaku ceramic form is associated with socio-economic activities; the exploitation of the island coastal area was distinct between the Tiwanaku Period and the Inca Period.

\section{Artefacts Horizontal Contextualisation: Results and Discussion}

Within the 12 test trenches excavated at Puncu (see Fig. 4), 1137 ceramic fragments have been found, including 743 Tiwanaku and pre-Tiwanaku fragments ( $\leq$ AD 1150) and 394 post-Tiwanaku fragments; the majority of these are probably related to Inca material(AD 1400-1532). By transposing in plan all these ceramic fragments from the various stratigraphic units (horizontal contextualization), it is possible to observe that $90.3 \%$ of the 
(pre-) Tiwanaku fragments have been found in the Puncu 2 sector, and that $87.3 \%$ of postTiwanaku and/or Inca fragments come from Puncu 1. The Inca harbour area (Puncu 1) is not in the same location as the one of the Tiwanaku period (Puncu 2), not only because the lake level and the paleo-shores location were different, but also because the cultural use of Puncu does not correspond to the same socio-economic, political and ritual concerns between these two periods (Fig. 7).

During the Tiwanaku Period, the lake level was ca. $5 \mathrm{~m}$ lower than the present one. The coastline is characterized by a non-submerged planar area of ca. $20 \mathrm{~m}$ wide and was used throughout the entire headland's eastern side forming the Island of the Sun's end (Puncu 2). Starting ca. AD 800, a part of this coastline was reinforced through a modification of the banks, constituted of stone agglomerate by artificially creating a relatively horizontal surface uphill of it. Boats could eventually dock at this structural modification when the lake's water level was high, but it was more likely boats with low draught would simply be stranded on the beaches. During the Inca Period, the Tiwanaku littoral area was completely submerged and the latter will favor the Puncu 1 site (see Fig. 7).

This distinction reflects in a diachronic manner the variability of the lacustrine basin occupation and the variability of the lake utilisation. First, there is a traditional break in the use of harbour areas between the Tiwanaku and the Inca Periods. Second, we believe that the location of the Inca harbour highlights the foreign origin of these. The Puncu Inca area is in fact poorly protected from the winds and lake currents, which, during the dry season, come from the west and can be very violent. In comparison, it is noted that not only is Puncu Tiwanaku located in a protected area to the east, but also that most of the settlement sites of this period are located on the island eastern shore (Stanish and Bauer 2004: 36, Fig. 2.6). Tiwanaku populations, native and originating from the lacustrine basin, must have been experienced navigators. They knew their ecosystem and developed their harbour areas in favourable sectors, whereas the Incas, foreigners, created a harbour area adapted to their needs during the transformation of the island space into a "sanctuary island". Finally, we believe that these observations bring a new dimension to the study of the use of Lake Titicaca during the Tiwanaku Period, because, a priori, it had a different status (mainly socio-economic space) than that of the Incas (mythical space). It is possible to conclude that the Tiwanaku populations used the entire lake for fishing activities and to access the various island occupation sites, whereas the Incas regulated lake navigation by restricting it exclusively to pilgrimage activities. Access to the Island of the Sun had to be strictly controlled between Yampupata and Puncu during this last period (see Fig. 7).

\section{The Coastal Area Location: Conclusion}

All water depths, both those cited in from the excavations discussed here and those quoted in scientific literature, are relative to reference "zero" which corresponds to $3809.7 \mathrm{~m}$ elevation. At the moment, the analysis of the contexts of discoveries makes it possible to determine that the water level of Titicaca observed at "Puncu Tiwanaku" was much lower, and that the water level of the "Puncu Inca" was almost identical to today's measurements. In particular, for test trenches \#8, \#11, \#10 and \#12 (Puncu 2), mainly dating from the Tiwanaku Period, the general pattern of these lake fluctuations can be reconstructed:

- Tiwanaku IV Occupation (AD 500-800); Artefacts from lower stratigraphic units (US6 to US10) show that all these levels are connected. They actually belong to an ancient paleo-terrestrial sedimentary accumulation that was later disrupted by several lake 

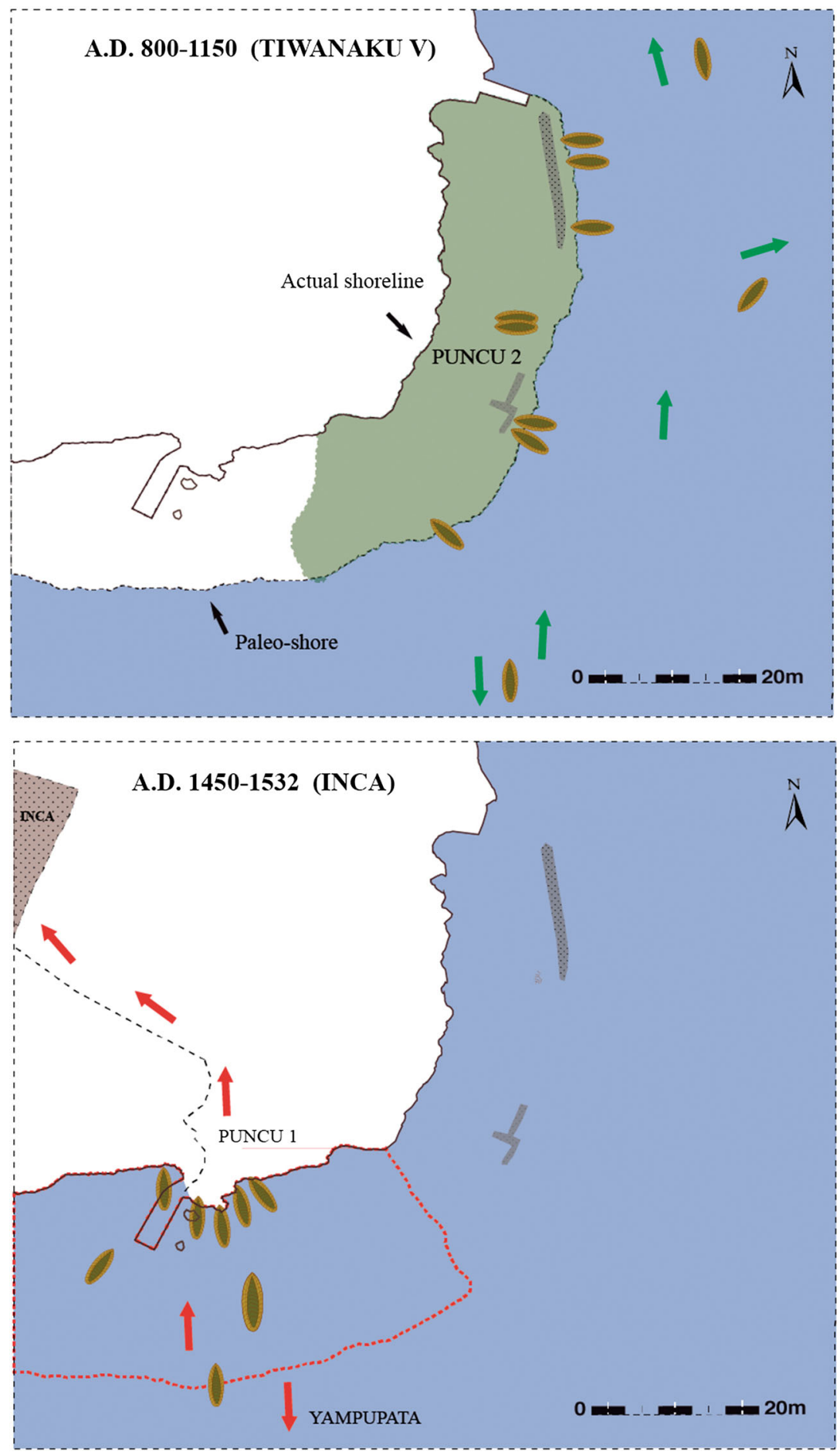

Fig. 7 Location of the Tiwanaku and Inca port areas-map (Puncu) (Delaere 2016: 170) 

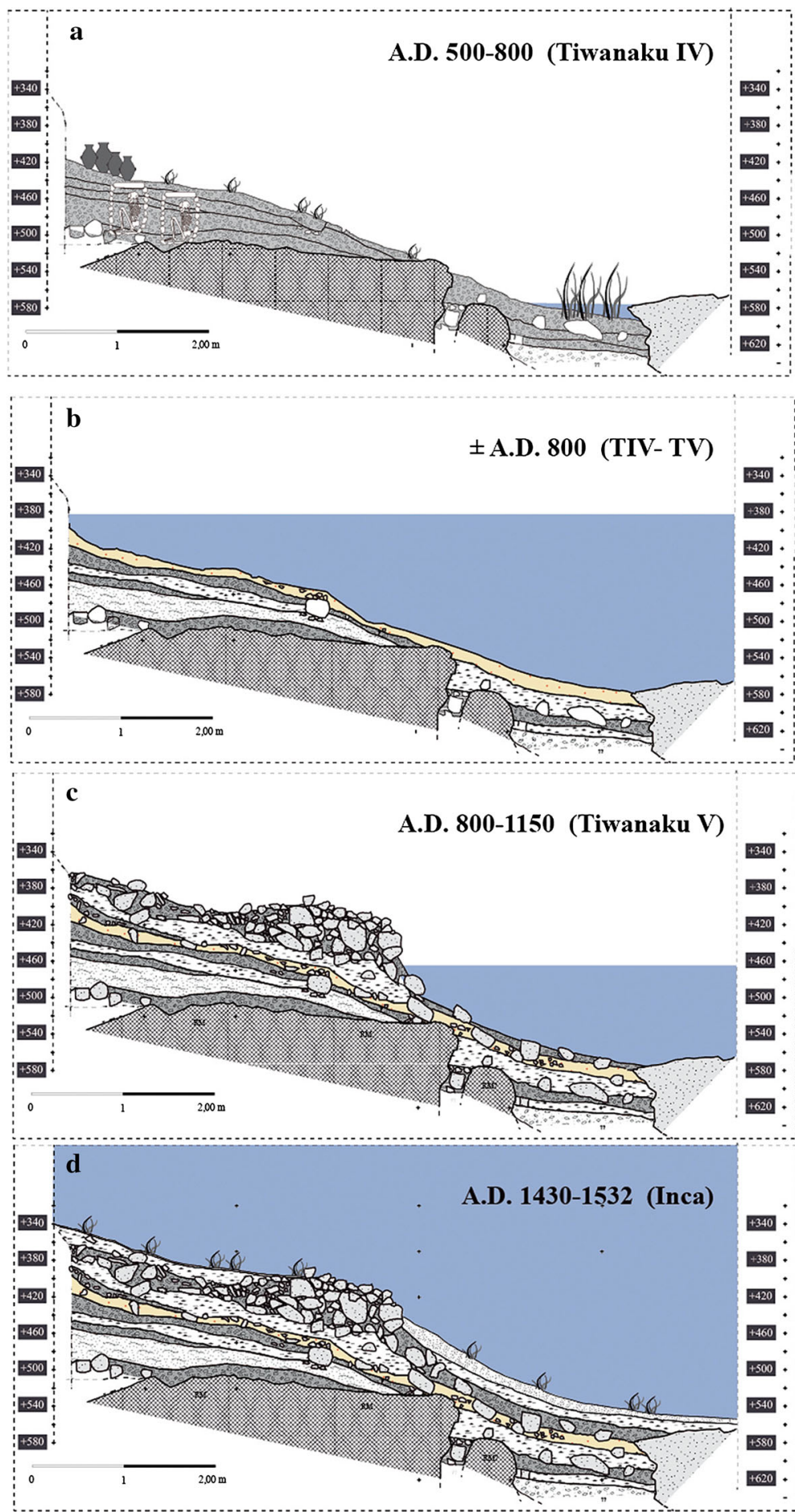

Fig. 8 Location of the Tiwanaku and Inca coastal areas-cross-sections (Puncu 2) (Delaere 2016: 157) 
fluctuation events. This level is characterized by the presence of graves and fragments of an old vegetal cover (wood with bark). Downhill measurement ratings indicate that the paleo-coastline must have been $6.2 \mathrm{~m}$ deep, or more, between 6 and $10 \mathrm{~m}$ (Fig. 8a).

- "Crisis" event (around AD 800); during a crisis period at ca. AD 800, especially because of the large number of artefacts associated with the lower level occupation, Lake Titicaca has suddenly grown at least three times. The backwash phenomenon (removal current), typical of (paleo) coastal areas, has grazed the entire coastline during a limited period and is reflected in the formation of new, modified archaeological sedimentary deposits from the previous occupation floor. The entire area was then covered by a homogeneous lacustrine layer, US5, whose uphill measurements indicate that the level of the lake must have been at $4 \mathrm{~m}$ deep, or less, between 2 and $4 \mathrm{~m}$ (Fig. 8b).

- Tiwanaku V Occupation (AD 800-1150); this upper level is characterized by the presence of a pile of stones of anthropogenic origin. This corresponds to a construction intended to reinforce the bank and to delimit an approximately flat area upstream of it. This arrangement is probably the result of a reaction of the local populations to the previous events of lake fluctuations. Depending on this structure's foundation, the water level of the lake must have been at a maximum depth between 4.6 and $7 \mathrm{~m}$ (Fig. 8c).

- Utilisation by the Incas (AD 1400-1532); the number of artefacts from this period is very low in Puncu 2, but indicates nevertheless that the entire area was submerged (Fig. 8d). The data acquired in test trenches \#2, \#4 and \#6 locate the lake water level at a depth between 0 and $1 \mathrm{~m}$, notably with the evidence of a load shift and numerous ceramic fragments in the vicinity of the present coastline.

The phenomenon of annual and multi-annual fluctuations, attested in the twentieth century, must have been identical during these periods. As a consequence, there are no linear and static models of the lake level fluctuations over time. However, these estimates of the lake level are essential to locate the paleo-shores, but the level determination for each period is not set in absolute terms.

The variability of the artefacts discovered under water will ultimately allow various research issues to be addressed from a diachronic perspective, in particular the study of practices associated with the littoral space (harbour area, specialised activity areas proper to the littoral, etc.), the study of navigation techniques on the lake (boats and routes) and the analysis of the circulation of goods and people between the island area and the continent (trade and pilgrimage). The location of the Tiwanaku coastal area under more than $4 \mathrm{~m}$ of water opens up outstanding research prospects, as there are more than $300 \mathrm{~km}$ of lacustrine coasts in the Bolivian part of Lake Titicaca that have never been studied. This represents more than $560 \mathrm{~km}^{2}$ of territory today submerged only for the lago menor.

Acknowledgements We would like to thank all the members, persons in charge and partners of the Titicaca Project 2012-2014 who, whatever the nature of their involvement, contributed to the realisation of this major undertaking, in particular: Prof. Peter Eeckhout, Prof. Éric Rieth, Prof. Charles Stanish, Marcial Medina Huanca, Jose Capriles, Maria Guerra, as well as all the diver archaeologists, restorers, topographer and technicians. We also thank the ULB, the F.R.S.-FNRS and specifically Ruth Fontenla Álvarez for her analysis of the ceramic fragments of Puncu, Arnaud Bourguignon for the text translation, and Florence Doyen for her editing comments. 


\section{References}

Bass GF (1970) Archaeology under water, 2nd edn. Editions Penguin Books Ltd, Harmondsworth

Bauer BS, Stanish C (2001) Ritual and pilgrimage in the ancient andes, the islands of the sun and the moon. University of Texas Press, Austin

Binford M, Kolata AL (1996) The natural and human setting. In: Kolata AL (ed) Tiwanaku and its hinterland, archaeology and paleoecology of an andean civilization, vol 1. Agroecology. Smithsonian Institution Press, Washington, pp 23-56

Binford MW, Kolata AL, Brenner M, Janusek JW, Seddon MT, Abbott MB, Curtis JH (1997) Climate variation and the rise and fall of an andean civilization. Quat Res 47(2):235-248

Boulangé P, Aquize Jaen E (1981) Morphologie, hydrographie et climatologie du lac Titicaca et de son bassin versant. Rev Hydrobiol Trop 14(4):269-287

Delaere C (2016) Le patrimoine subaquatique du lac Titicaca, Bolivie. Utilisation et perception de l'espace lacustre durant la période Tiwanaku (500-1150 PCN). Unpublished Ph.D. dissertation, Université libre de Bruxelles

Evans AM, Keith ME (2011) Potential contribution of a maritime cultural landscape approach to submerged prehistoric resources, Northwestern Gulf of Mexico. In: Ford B (ed) The Archaeology of maritime landscapes-when the land meets the sea, vol 2. Springer, New York, pp 163-178

Flatman J (2011) Places of special meaning: westerdahl's comet, "agency", and the concept of the "maritime cultural landscape". In: Ford B (ed) The archaeology of maritime landscapes-when the land meets the sea, vol 2. Springer, New York, pp 311-329

Flemming NC (1983) Survival of submerged lithic and bronze age artifact sites: a review of case histories. In: Masters PM, Flemming NC (eds) Quaternary coastlines and marine archaeology: towards the prehistory of land bridges and continental shelves. Academic Press, New York, NY, pp 135-173

Janusek J (2013) Social diversity, ritual encounter, and the contingent production of Tiwanaku. In: Vranich A, Stanish C (eds) Visions of Tiwanaku, vol 78. Monograph. Cotsen Institute of Archaeology Press, Los Angeles, pp 197-210

Mourguiart Philippe, Wirrmann Denis, Fournier Marc, Servant Michel (1992) Reconstruction quantitative des niveaux du petit lac Titicaca au cours de l'Holocène. Comptes Rendus Acad Sci Paris 315(2):875-880

Ponce Sanginés C (1992) Arqueología subacuática en el lago Titikaka. In: Sanginés CP, Reinhard J, Ortiz MP, Pareja E, Ticlla L (eds) Exploraciones arqueológicas subacuáticas en el Lago Titikaka. Editorial La Palabra Producciones, La Paz, pp 11-328

Posnansky A (1912) Guía general ilustrada para la Investigación de los Monumentos prehistóricos de Tihuanacu é islas del sol y la luna (Titicaca y Koaty). Imprenta y Litografía Boliviana - Hugo Heitmann, La Paz

Ronchail J, Espinoza JC, Labat D, Callède J, Lavado W (2014) Evolución del nivel del lago Titicaca durante el sieglo XX. In: Pouilly M, Lazzaro X, Point D, Aguirre M (eds) Línea base de conocimientos sobre los recursos hidrológicos e hidrobiológicos en el sistema TDPS con enfoque en la cuenca del Lago Titicaca. Talleres Gráficos Pérez, La Paz, pp 1-13

Seddon M (1998) Ritual, power and the development of a complex society: the island of the sun and the Tiwanaku State. Ph.D. dissertation, Departement of Anthropology, University of Chicago

Stanish C (2001) Formación estatal temprana en la cuenca del Lago Titicaca, Andes Surcentrales. Boletín de Arqueología PUCP 5:189-215

Stanish C (2011) Lake Titicaca. Legend, myth and science. Cotsen Institute of Archaeology Press, Los Angeles

Stanish C, Bauer BS (2004) The settlement history of the island of the sun. In: Stanish C, Bauer BS (eds) Archaeological research on the islands of the sun and moon, lake Titicaca, Bolivia: final results from the Proyecto Tiksi Kjarka, vol 52. Monograph. Cotsen Institute of Archaeology Press, Los Angeles, pp 23-42

Westerdahl C (1992) The maritime cultural landscape. Int J Naut Archaeol 21(1):5-14 